\title{
LITERASI MEDIA SISWA DALAM PENGGUNAAN INTERNET DI SEKOLAH ALAM BOGOR
}

\author{
${ }^{1}$ Wahyuni Choiriyati, ${ }^{2}$ Vivit Wardah Rufaidah, ${ }^{3}$ Ade Tuti Turistiati \\ ${ }^{1}$ Universitas Gunadarma, ${ }^{2}$ Pusat Perpustakaan dan Penyebaran Teknologi Pertanian Kementan \\ ${ }^{3}$ Institut Ilmu Sosial dan Manajemen STIAMI
}

E-mail: choiri@staff.gunadarma.ac.id,vivitwardah@gmail.com, ade.tuti.turistiati@gmail.com

\begin{abstract}
This media literacy research describes the reality of using internet media by students of Alam Middle School-Bogor (SMP Alam Bogor). The school has the concept of integration consisting three pillars of education and a key factor in humanity's excellence as an element of teaching. The three pillars include faith, knowledge and leadership with the motto more than a school, it's a community. SMP Alam Bogor was chosen because it minimizes the use of paper in the education process. In addition, all communication and learning activities are carried out through a login system on the school website. The purpose of this study is to analyze phenomena in more detail and narrative with the Individual Competence Framework as the main basis for measuring and describing media literacy for students of SMP Alam Bogor. The population in this study were all students of SMP Alam Bogor, with $68 \%$ male students and $32 \%$ female students. The questionnaire was chosen as a data collection technique. The sample was determined by simple random sampling with the aim that all populations have the same opportunity to become respondents. The results showed $48 \%$ of students at SMP Alam Bogor used chatting facilities to discuss school work issues and $31 \%$ discussed personal problems. The ability of students to use the internet to improve media literacy is quite good, it is seen that $87.8 \%$ of students are able to produce media content in the form of blogs that they make themselves, while the remaining $12.2 \%$ do not have blogs. The analysis showed that the majority of students at SMP Alam Bogor solved the problem independently (36.6\%) and asked friends, relatives, teachers when they had difficulty in accessing the internet (21.9\%). The category of social competence in the use of the internet places students of SMP Alam Bogor in the medium category.
\end{abstract}

Keywords: Media literacy, internet use, social competency indicators

\begin{abstract}
Abstrak
Riset literasi media ini mendeskripsikan realitas penggunaan media internet oleh siswa SMP Alam Bogor yang merupakan sekolah berkonsep integrasi tiga pilar pendidikan. Sekolah Alam menempatkan faktor kunci keunggulan umat manusia sebagai elemen pengajaran. Tiga pilar tersebut meliputi iman, ilmu dan kepemimpinan dengan motto more than a school, it's a community. SMP Alam Bogor dipilih karena meminimalkan pemakaian kertas dalam proses pendidikan. Selain itu, aktivitas komunikasi dan pembelajaran semua dilakukan melalui system login di website sekolah. Tujuan penelitian ini untuk menganalisis fenomena secara lebih rinci dan naratif dengan Individual Competence Framework sebagai dasar utama mengukur dan menggambarkan media literacy siswa SMP Alam (SM) Bogor. Populasi dalam penelitian adalah seluruh siswa SMP Alam Bogor sebanyak $68 \%$ siswa laki-laki dan 32\% siswa perempuan. Kuisioner dipilih sebagai teknik pengumpulan data. Sampel ditentukan secara simple random sampling dengan tujuan semua populasi memiliki kesempatan sama menjadi responden. Hasil penelitian menunjukkan $48 \%$ siswa SMP Alam Bogor memanfaatkan fasilitas chatting untuk
\end{abstract}


mendiskusikan masalah tugas sekolah dan $31 \%$ diskusi masalah pribadi. Kemampuan siswa dalam memanfaatkan internet untuk meningkatkan media literacy cukup baik, terlihat $87,8 \%$ siswa mampu memproduksi konten media berupa blog yang mereka buat sendiri, sedangkan sisanya $12,2 \%$ tidak memiliki blog. Hasil analisis menunjukkan bahwa sebagian besar siswa SMP Alam Bogor menyelesaikan permasalahan secara mandiri $(36,6 \%)$ dan bertanya kepada teman, saudara, guru ketika mereka mengalami kesulitan dalam mengakses internet (21,9\%). Adapun kategori kompetensi social dalam penggunaan internet menempatkan siswa SMP Alam dalam kategori medium.

Kata Kunci: Literasi media, penggunaan internet, indikator kompetensi sosial

\section{PENDAHULUAN}

Salah satu agenda World Summit on the Information Society (WSIS), di Jenewa pada tahun 2003 dan di Tunisia tahun 2005 adalah membangun masyarakat informasi pada tataran global. Sasarannya adalah terwujudnya masyarakat global. Di Indonesia visi Masyarakat Informasi Indonesia harus tercapai pada tahun 2015. Konsekuensi atas kesepakatan WSIS menjadikan informasi bersifat borderless, dapat mengalir ke mana saja tanpa batas negara. Perkembangan teknologi dan informasi yang pesat memungkinkan siapa pun dapat mengakses, menggunakan, dan berbagi informasi serta pengetahuan. Seiring dengan ledakan informasi dan penerapan Teknologi Informasi dan Komunikasi (TIK) tersebut, masyarakat akan berkembang memasuki peradaban masyarakat informasi (information society). Information society yaitu peradaban di mana informasi sudah menjadi komoditas utama dan interaksi antarmanusia sudah berbasis teknologi informasi dan komunikasi (Sumiaty, 2014: 77).

Dalam mendalami media dan komunikasi, salah satu kajian penting yang perlu diperhatikan adalah tentang literasi media. Hal ini terkait dengan salah satu aspek dalam kajian media dan komunikasi yaitu bagaimana seseorang menerima dan memahami informasi atau pesan yang disampaikan melalui media. Penelitian tentang literasi media telah dilakukan oleh beberapa peneliti terdahulu, baik di dalam maupun luar negeri. Beberapa penelitian tersebut menghasilkan suatu temuan yang dimanfaatkan untuk mengembangkan suatu program literasi media yang dilakukan oleh Pemerintah maupun swasta.

Literasi media adalah kemampuan untuk mengakses, menganalisis, mengevaluasi, dan mengkomunikasikan pesan dalam berbagai bentuknya tercantum dalam National Leadership Conference on Media Education (Hobbs dalam Juditha, 2013). Definisi lain tentang literasi media dikemukakan oleh Kriyantono (2007) yang menyebut literasi media sebagai melek media. Melek media adalah keterampilan untuk menganalisis isi media. Hartanto (2010) juga mengartikan literasi media sebagai kritis media, yaitu dapat mengkritisi isi media. Selain itu, definisi literasi media menurut Brown dalam Pawito (2007) adalah kemampuan menganalisis dan mengapresiasi karya-karya literatur dan karya-karya budaya yang disebarluaskan melalui media massa serta kemampuan untuk berkomunikasi secara efektif dan menggunakan media massa untuk berbagai maksud dan tujuan. Karya-karya yang dianalisis dan diapresiasi meliputi bentuk-bentuk karya sastra, buku-buku dengan berbagai karakter, karya jurnalistik, acara siaran televisi dan radio, bahkan berbagai bentuk publikasi melalui internet.

Sementara Devito dalam Arifianto (2013) mendefinisikan literasi media sebagai kemampuan untuk memahami, menganalisis, mengakses dan memproduksi pesan komunikasi massa. Dari berbagai definisi literasi media secara umum, Livingstone (2004) menjabarkan empat komponen yang terkandung di dalam literasi media, yaitu akses, analisis, evaluasi, dan pembuatan konten. Secara keseluruhan, literasi media 
merupakan analisis dan evaluasi terhadap isi media, seperti televisi.

Penelitian tentang literasi media sudah banyak dilakukan, salah satu contohnya adalah penelitian Juditha (2013) yang berjudul "Literasi Media pada Anak di Daerah Perbatasan Indonesia dan Timor Leste". Hasil penelitian tersebut menunjukkan bahwa anak di perbatasan Kabupaten Belu Nusa Tenggara Timur yang berumur 10-14 tahun mampu mengakses dan memahami isi pesan, memahami tujuan pesan media, dapat mengidentifikasi pengirim pesan melalui media dan apa isi pesan tersebut. Selain itu mereka mampu menilai pesan yang diterima kemudian dibandingkan dengan perspektif diri sendiri. Dengan demikian, mereka memiliki literasi media yang baik meski berada di daerah perbatasan.

Penelitian lain mengenai literasi media adalah penelitian Masitoh (2013) mengenai tayangan talkshow Indonesia Lawyer's Club (ILC). Penelitian tersebut menyimpulkan bahwa konsumen tayangan ILC memiliki literasi media yang baik. Acara ILC merupakan tayangan yang berkaitan dengan hukum namun penelitian tersebut tidak menunjukkan adanya hubungan literasi media dengan latar belakang pendidikan karena baik konsumen yang berlatar belakang pendidikan hukum atau bukan hasilnya sama. Namun, penelitian tersebut menunjukkan adanya hubungan literasi media dengan profesi. Konsumen yang masih berstatus mahasiswa memiliki literasi media yang lebih baik dilihat dari daya analisis dan evaluasinya terhadap tayangan tersebut.

Konsep ini diterapkan pada beragam gagasan yang berupaya untuk menjelaskan bagaimana media menyampaikan pesan-pesan mereka, dan mengapa demikian. Dalam masyarakat media, ketika kontak dengan media menjadi sesuatu yang esensial dan tak terhindarkan, media literacy adalah sebuah keterampilan yang diperlukan oleh warga negara guna berinteraksi dengan layak terhadap media dan menggunakannya dengan rasa percaya diri (Hayuningrat, 2010).

Perkembangan teknologi informasi yang terjadi saat ini ikut berperan dalam memengaruhi literasi media terutama pelajar. Para pelajar (siswa) mau tidak mau dihadapkan dengan lingkungan yang menyediakan berbagai alternatif saluran informasi yang dapat digunakan untuk memenuhi kebutuhan informasi mereka. Hal ini sesuai dengan yang diungkapkan oleh Purwono (2008), yang mengatakan bahwa kemajuan teknologi informasi membawa perubahan mendasar dalam memenuhi kebutuhan informasi yang diperlukan. Salah satu dari teknologi tersebut adalah internet. Internet merupakan sumber informasi yang tidak terbatas dan dapat diakses kapan dan dimana pun selama 24 jam. Sementara itu, sumber-sumber tercetak mempunyai keterbatasan akses yaitu tempat dan waktu serta kebaruan dari koleksi tersebut.

Adanya teknologi informasi menciptakan berbagai saluran informasi pendidikan yang memanfaatkan teknologi informasi. Keberadaan internet sebagai salah satu saluran informasi yang berbasiskan teknologi menjadi salah satu pesaing peran perpustakaan perguruan tinggi sebagai sumber informasi bagi siswa. Hal ini sesuai dengan yang diungkapkan oleh Husein (2006), yang menyatakan bahwa semakin banyak masyarakat modern yang lebih mengandalkan internet, 'keramahan' mesin pencari (search engine) seperti Google (www.google.com) dan Yahoo! (www.yahoo.com), serta mesin pencari lainnya (Altavista, Ask Jeeves, dan sebagainya) yang dipercaya jauh me ngalahkan layanan perpustakaan. Sehingga jika diamati, siswa saat ini dalam menemukan informasi tidak hanya memanfaatkan perpustakaan sekolah dan buku umum saja, namun juga memanfaatkan internet.

Saat ini penggunaan media internet sebagai saluran informasi semakin meningkat. Penelitian Aplebee yang meneliti penggunaan internet di kalangan warga sekolah di Australia menemukan bahwa pada tahun 1997, hanya ada kurang dari 50\% orang yang menggunakan internet dan dari angka itu hanya $13 \%$ yang menggunakan untuk kegiatan keseharian. Sementara di tahun 2000, lebih dari $92 \%$ orang menggunakan 
internet dan $25 \%$ diantara mereka menyatakan menggunakan internet untuk kebutuhan sehari-hari.

Berdasarkan latar belakang pemikiran tersebut, peneliti merumuskan permasalahan: Sejauh mana literasi media siswa SMP Alam Bogor dalam penggunaan media internet yang dilihat dari personal competence dan social competence?

\section{KERANGKA KONSEPTUAL}

Konsep literasi media telah digunakan secara umum dalam kurun waktu seperempat abad. Buckhigam (2004) menyatakan bahwa masih ada kebingungan dan ketidaksepakatan tentang bagaimana konsep literasi media yang harus didefinisikan. Perkembangan konsep literasi media dijelaskan melalui sebuah analogi terhadap print literacy, yang menimbulkan beberapa pertanyaan dasar tentang konsep literasi media, yaitu sampai sejauh mana media yang dilihat dapat mewujudkan suatu bentuk bahasa yang mirip dengan bahasa tertulis? apakah pengguna perlu belajar untuk menggunakan dan menafsirkan media, karena mereka harus belajar untuk menafsirkan media cetak? dan apakah ada literasi tunggal yang berlaku di seluruh jajaran media kontemporer? Pertanyaan-pertanyaan ini dan isu-isu terkait telah memicu perdebatan teoritis yang cukup besar dan mewarnai perkembangan konsep literasi media (Buckingham, 2004, Kress, 2003; Messaris, 1994).

Beberapa faktor yang saling berhubungan yang merupakan hambatan dalam pembentukan literasi media adalah faktor status sosial dan status ekonomi. Faktor tersebut menjadi hambatan bagi anak-anak untuk mengakses internet, meskipun tidak sebesar dalam menghambat akses pada media seperti radio atau televisi. Faktor lain yang juga berpotensi untuk mengurangi akses mereka terhadap media yaitu cacat dan etnis, peran individu serta motivasi. Selain itu, hambatan juga dapat berupa ketersediaan, kuantitas dan kualitas akses internet.

\section{Media Baru dalam Pemikiran McLuhan Pemikiran media baru dalam}

McLuhan (1968) memberikan banyak inspirasi terkait riset dengan topic media baru. Pemikiran yang mendasri bahwa the medium is the message dapat diterapkan melalui internet yang termuat dalam bentuk-bentuk word wide web, seperti situs-situs berita online. Usulan pemikiran McLuhan mengenai "kampung dunia" atau global village tampaknya semakin nyata dengan realitas internet. Lebih lanjut McLuhan juga membangun berbagai pemikiran brilian mengenai distingsi format media. Penelitiannya membandingkan media online dengan tradisional dalam menyampaikan informasi.

Saat ini belum terlihat teori baru yang dikembangkan dengan Internet dan Word wide web. Banyak riset pada komunikasi cyber telah dilakukan dengan pertanyaanpertanyaan spesifik, terutama tentang efek dan manfaat media baru. Konsep ini dari interaktivitas, hypertexts, dan multimedia menjadi fokus berbagai penelitian. Satu teori yang telah dikembangkan adalah pemikiran Roger Fidler tentang mediamorfosis, yang berusaha menjelaskan hubungan antara media baru dengan media lama. Fidler mempresentasikan tentang mediamorfosis untuk membantu memahami jenis perubahan di bidang media ini. Mediamorfosis sendiri diartikan sebagai "perubahan bentuk media komunikasi, biasanya disebabkan oleh interaksi kompleks dari kebutuhan-kebutuhan penting, tekanan- tekanan kompetitif dan politis, dan inovasi- inovasi sosial dan teknologi" (Severin dan Tankard, 2007 dalam Sumiaty, 2014: 87).

\section{Individual Competence Framework sebagai Alat Ukur Literasi media}

Individual Competence adalah kemampuan seseorang dalam menggunakan dan memanfaatkan media. Individual competency di dalamnya termasuk kemampuan untuk menggunakan, memproduksi, menganalisis, dan mengkomunikasikan pesan melalui media (European Commission, 2009). Individual competence ini terbagi kedalam dua kategori yaitu : 
(1) Personal Competence, yaitu kemampuan seseorang dalam menggunakan media dan menganalisis konten-konten media. Personal competence terdiri atas dua variabel yaitu (a) Technic skills, yaitu kemampuan teknik dalam menggunakan media, artinya seseorang mampu mengoperasikan media dan memahami semua jenis instruksi yang ada di dalamnya dan (b) Critical understanding, yaitu kemampuan kognitif dalam menggunakan media seperti kemampuan memahami, menganalisis, dan mengevaluasi konten media,

(2) Social competence, yaitu kemampuan seseorang dalam berkomunikasi dan membangun relasi sosial lewat media serta mampu memproduksi konten media. Social competence terdiri atas communicative abilities yaitu kemampuan komunikasi dan partisipasi melalui media. Communicative abilities ini mencakup kemampuan untuk membangun relasi sosial serta berpatisipasi dalam lingkungan masyarakat melalui media, dan kemampuan dalam membuat dan memproduksi konten media.

Berdasarkan indikator tersebut di atas, kemampuan literasi media seseorang dikelompokkan menjadi tiga yaitu: (1) Tipe basic, dimana individu masih memiliki keterbatasan dalam penggunaan media internet, mengetahui fungsi dasar internet tetapi digunakan untuk tujuan-tujuan tertentu tanpa arah yang jelas, kapasitas pengguna untuk berpikir secara kritis dalam menganalisis informasi yang diterima masih terbatas, kemampuan komunikasi melalui media juga terbatas; (2) Tipe medium adalah mereka yang sudah fasih dalam penggunaan media, mengetahui fungsi dan mampu melaksanakan fungsi-fungsi tertentu, menjalankan operasi yang lebih kompleks, penggunaan media internet disesuaikan dengan kebutuhan, mengetahui bagaimana cara untuk mendapatkan dan menilai informasi yang dia butuhkan, serta menggunakan strategi pencarian informasi tersebut; dan (3) Tipe advanced adalah mereka yang sangat aktif dalam penggunaan media, sadar dan tertarik dalam berbagai regulasi yang memengaruhi penggunaannya, memiliki pengetahuan yang mendalam tentang teknik dan bahasa serta dapat menganalisis kemudian mengubah kondisi yang memengaruhinya, dan dapat melakukan hubungan komunikasi dan penciptaan pesan serta di bidang sosial, pengguna mampu mengaktifkankerjasama kelompok yang memungkinkan dia untuk memecahkan masalah (European Commission, 2009).

\section{Information Communication Technology Literacy (ICT Literacy)}

ICT Literacy diartikan oleh American

Library Association (ALA) sebagai "kemampuan mengenali kapan informasi dibutuhkan dan memiliki kemampuan untuk menemukan, mengevaluasi, dan menggunakan informasi secara efektif" (ALA, 1989). Penelitian tentang information literacy lebih banyak memusatkan perhatian pada cara dan sejauh mana informasi dievaluasi. Committee on Information Technology Literacy (1999) dalam penelitiannya menemukan bahwa bahwa sejumlah faktor kepercayaan, relevansi, harga, akurasi, objektivitas, kecukupan, jenis sumber informasi, dan etika penggunaan merupakan pertimbangan pengguna dalam dalam mengevaluasi informasi.

ICT literacy ditunjukkan dengan keterampilan kognitif dalam lingkungan digital untuk mendefinisikan, mengakses, mengelola, mengevaluasi, mengintegrasikan, membuat, dan mengkomunikasikan informasi. ICT literacy juga dirancang untuk mengukur kemampuan individu terhadap tujuh bidang kerja yaitu mendefinisikan (define), mengakses (access), mengevaluasi (evaluate), mengelola (manage), menintegrasikan (integrate), menciptakan (create), dan dan mengkomunikasikan informasi (communicate).

\section{Distingsi Literasi Internet}

Internet literacy sendiri memiliki banyak pengertian, dan di antaranya diartikan Doyle sebagai kemampuan dalam 
menggunakan pengetahuan teori dan praktik dalam hubungannya dengan internet sebagai medium komunikasi dan pengelolaan informasi. Perbedaan definisi pada computer literacy dalam (Mudjiyanto, 2012) terletak telah gagasan pada:

1. Pengetahuan teoretis dan praktik tentang komputer (hardware, software) dan internet (komunikasi, pencarian informasi);

2. Keyakinan diri mengenai komputer dan internet;

3. Penggunaan yang bertanggungjawab dan refleksi kritis mengenai komputer dan internet.

Uraian di atas menunjukkan beda di antara definisi computer literacy dan internet literacy terletak pada sisi, literasi komputer berhubungan dengan kemampuan mengetahui, memahami, dan mempraktikan komponen hardware dan software computer yang dibutuhkan untuk memanfaatkan fungsi komputer (misal untuk word processing maupun untuk beraktivitas komunikasi dan informasi melalui medium internet). Literasi internet yaitu kemampuan untuk melakukan aktivitas komunikasi, pencarian informasi dan sejenisnya melalui medium internet guna memenuhi kebutuhan yang dimungkinkan terjadi hanya bila seseorang telah memiliki literasi komputer (Mudjiyanto, 2012).

$$
\text { Mengikuti zamannya, maka }
$$
tumbuhnya e-literacy pada setiap generasi akan berbeda. Setiap negara terdiri dari masyarakat dengan beragam tingkat $e$ literacy/ICT literacy yang berbeda. Untuk menjawab permasalahan tersebut ada tiga tahapan strategi sebagai pendekatan efektif guna mengakselerasi peningkatan, yaitu:

1. Menciptakan konteks (demand creation);

2. Melibatkan teknologi (supply technology);

3. Mengubah perilaku (behaviour change).

Kemampuan e-literacy pada setiap individu akan memiliki pola yang berbeda sesuai dengan kebutuhan hidup dan kedewasaan masyarakat (Departemen Komunikasi dan Informatika RI, 2006).

\section{Kerangka Penelitian}

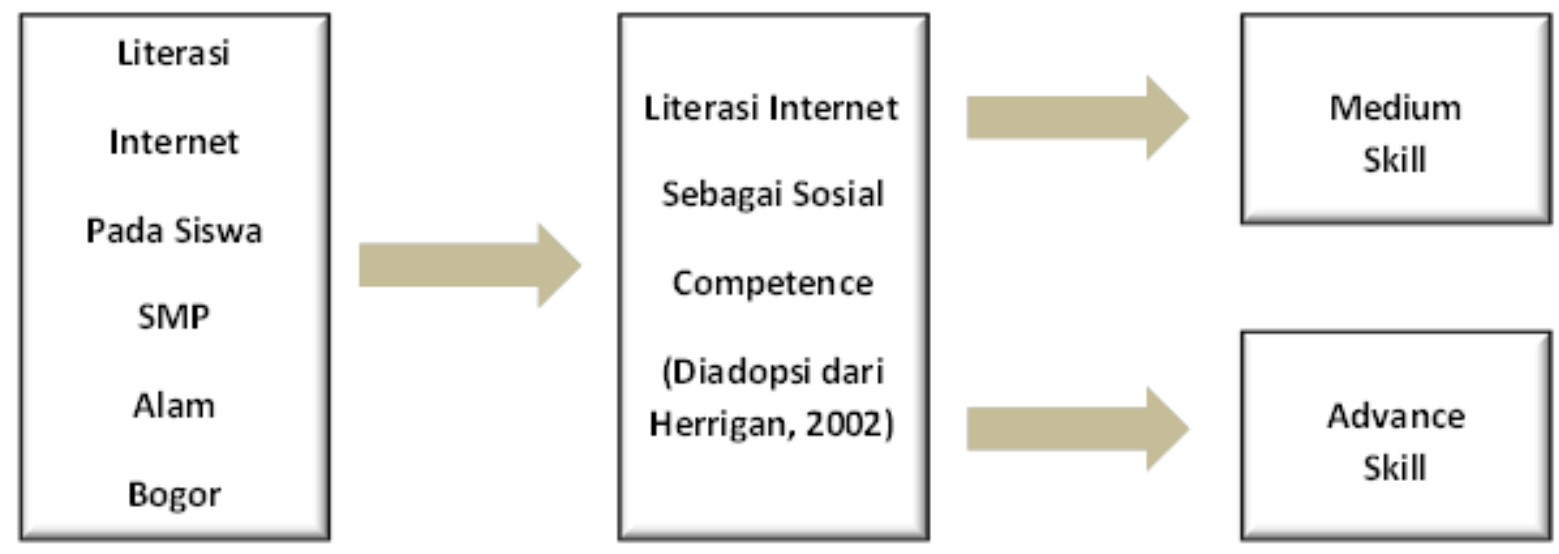

Sumber: Hasil Pemikiran Peneliti

\section{METODOLOGI PENELITIAN}

Penelitian ini menggunakan metode kuantitatif. Menurut Sugiono (2008) metode kuantitatif memandang realitas sebagai sesuatu yang diamati dengan panca indera, dapat divariabelkan menurut jenis, bentuk, warna, dan perilaku, dapat diukur, dan diverifikasi. Penelitian ini bertujuan untuk menganalisis dan mendeskripsikan realitas literasi media siswa SMP Alam Bogor yang merupakan sekolah dengan konsep integrasi tiga pilar pendidikan yang diyakini menjadi faktor kunci keunggulan umat manusia, yaitu pilar iman, ilmu dan kepemimpinan dengan motto more than a school it's a community. 
Pemilihan SMP Alam Bogor untuk penelitian ini dikarenakan SMP Alam Bogor termasuk sekolah yang menerapkan meminimalkan pemakaian kertas dalam proses belajar mengajar. Aktivitas komunikasi dan pembelajaran semua dilakukan melalui sistem melalui login tersendiri di website sekolah untuk setiap siswa termasuk penggunaan media internet dalam mendukung pembelajaran siswa. Literasi media siswa SMP Alama Bogor dalam penggunaan media internet merupakan suatu kemampuan dalam bentuk perilaku yang dapat diukur dan diverifikasi berdasarkan indikator-indikator penelitian. Peneliti menganggap bahwa metode kuantitatif adalah metode yang tepat dalam meneliti topik literasi media ini. Penelitian ini mengedepankan tujuan untuk mengambarkan fenomena yang diteliti secara lebih rinci dan naratif. Penelitian ini menggunakan Individual Competence Framework sebagai dasar utama untuk mengukur dan menggambarkan literasi media siswa SMP Alam (SM) Bogor khususnya dalam penggunaan media internet.

Populasi dalam penelitian ini adalah seluruh siswa pada SMP Alam Bogor. Teknik pengumpulan data yaitu memberikan kuesioner kepada siswa SMP Alam Bogor. Sampel dipilh secara simple random sampling dengan tujuan supaya semua anggota populasi memiliki kesempatan yang sama untuk menjadi responden.

\section{HASIL DAN PEMBAHASAN}

\section{Tingkatan Literasi media Berdasarkan Personal Competence}

Personal competence terdiri dari dua indikator yaitu technical skills dan critical understanding. Tingkatan literasi media siswa yang diukur berdasarkan technical skill setidaknya menggambarkan kemampuan menggunakan komputer dan internet (computer and internet skills), kemampuan menggunakan media secara aktif (balanced and active use of media) (European Commission, 2009).
Data responden siswa diketahui bahwa $68 \%$ berjenis kelamin laki-laki, dan 32\% perempuan. Keaktifan siswa dalam memanfaatkan media komputer salah satunya dilihat dari jumlah frekuensi penggunaan dan lamanya waktu yang digunakan oleh siswa dalam mengakses internet. Hasil penellitian menunjukkan bahwa data bahwa sebagian besar $(68,3 \%)$ siswa SMP Alam Bogor mengakses internet sebanyak 5-7 kali dalam seminggu dengan rata-rata lamanya waktu mengakses adalah 1-2 jam (31,7\%).

The Graphic, Visualization \& Usability Center, the Georgia Institute of Technology (2002) menggolongkan pengguna internet berdasarkan waktu yang diperlukan untuk mengakses internet sebagai berikut: (1) Heavy users, pengguna internet yang menghabiskan waktu lebih dari 40 jam per bulan (addicted users), (2) Medium users, pengguna internet yang menghabiskan waktu antara 10 sampai 40 jam per bulan, (3) Light users, pengguna internet yang memghabiskan waktu kurang dari 10 jam per bulan. Berdasarkan indikator tersebut, maka siswa SMP Alam Bogor termasuk dalam kelompok medium users, karena mereka mengakses internet sebanyak 3-4 jam/hari sehingga dalam waktu satu bulan mereka mengakses sebanyak 6-14 jam.

Tujuan dan motivasi siswa SMP Alam Bogor dalam menggunakan internet diketahui bahwa, walaupun rerata tidak terlalu jauh tetapi mayoritas siswa bertujuan untuk chating dan mencari informasi masing-masing 19,5\%. Apabila dikaitkan dengan penelitian Horrigan juga menggolongkan aktifitasaktifitas internet yang dilakukan para pengguna internet menjadi empat kelompok kepentingan penggunaan internet, yaitu: (1) Email, (2) Aktifitas kesenangan (fun activities) yaitu aktifitas yang sifatnya untuk kesenangan atau hiburan, seperti: online untuk bersenang-senang, klip video/audio, pesan singkat, mendengarkan atau download musik, bermain game, dan chatting. (3) Kepentingan informasi (information utility) yaitu aktifitas internet untuk mencari informasi, seperti: informasi produk, informasi perjalanan wisata, cuaca, informasi 
tentang film, musik, buku, berita, informasi sekolah, informasi kesehatan, pemerintah, informasi keuangan, informasi pekerjaan, atau informasi tentang politik, dan (4) Transaksi (transaction), yaitu aktifitas transaksi (jual beli) melalui internet, seperti: membeli sesuatu, memesan tiket perjalanan, dan online banking.

Berdasarkan apa yang disampaikan oleh Horrigan, temuan diketahui hanya 2,4\% saja siswa SMP Alam Bogor yang menggunakan internet untuk transaksi. Aktifitas-aktifitas tersebut menurut European Commision (2009) dikategorikan sebagai penggunaan internet tingkat tinggi yang termasuk dalam indikator technical skill.B erdasarkan hasil analisis menunjukkan bahwa kondisi siswa yang masih belum memiliki penghasilan sendiri menyebabkan aktifitas mereka terkait berbelanja online dan aktifitas perbankan masih belum menunjukkan jumlah yang besar.

Pada indikator technical skill, yaitu kemampuan dalam memanfaatkan media internet secara aktif dan mengembangkan strategi-strategi pencarian informasi yang efektif, siswa SMP Alam Bogor termasuk pada tingkatan literasi media tipe "advanced" dan "medium". Hal ini dikarenakan hasil analisis menunjukkan bahwa sebagian besar siswa SMP Alam Bogor akan menyelesaikan permasalahan secara mandiri $(36,6 \%)$ dan juga bertanya kepada teman, saudara, guru ketika mereka mengalami kesulitan dalam mengakses internet $(21,9 \%)$.

Dalam mengaskses internet, selalu ditemukan hambatan dan kesulitan yang ditemui oleh semua siswa, oleh sebab itu dituntut kemampuan siswa dalam mengembangkan strategi pencarian informasi yang lebih efektif. Coetzee (2000) mengungkapkan beberapa faktor yang menentukan keberhasilan seseorang dalam mengakses informasi di internet guna memenuhi kebutuhan informasinya, faktorfaktor tersebut salah satunya adalah faktor yang berkaitan dengan personalitas seseorang, yang antara lain semangat untuk berusaha mencari informasi meskipun pernah gagal, motivasi, keinginan mengakses dari sumber lain, dan kemampuan mengakses informasi secara sistematis. Hal ini dapat dikatakan bahwa seseorang yang memiliki kemampuan literasi media tipe advanced tidak akan menyerah atau berhenti ketika dirinya mengalami kesulitan dalam mengakses informasi.

$$
\text { Critical Understanding yang }
$$
digunakan untuk melihat tingkatan literasi media siswa SMP Alam Bogor ini menunjukkan kemampuan kognitif dalam menggunakan media seperti kemampuan memahami, menganalisis, dan mengevaluasi konten media (European Commision, 2009). Fedorov (2011) mengatakan bahwa seseorang yang memiliki pengetahuan untuk menganalisis secara kritis terhadap fungsi dari media internet dan terhadap informasiinformasi yang disajikan di internet dapat dikatakan sebagai orang yang memiliki tingkatan literasi media tipe advanced. Berdasarkan analisis yang dilakukan, menunjukkan bahwa pemahaman siswa SMP Alam Bogor dalam melihat informasi yang ada di internet sudah baik. Hal ini dilihat dari berbagai strategi yang dilakukan oleh siswa SMP ALam Bogor dalam mendapatkan informasi yang paling sesuai dengan kebutuhan. Selain itu siswa juga memperhatikan masalah keterpercayaan, keakuratan $(61 \%)$, keterbaruan informasi di internet melalui pengecekkan terhadap pengarang artikel di internet $(52 \%)$, daftar referensi yang digunakan $(40 \%)$, dan tahun pembuatan internet. Hal ini menunjukkan bahwa persepsi mereka dalam mengakses informasi sudah baik seperti yang disampaikan oleh Fedorov (2011) bahwa seseorang dengan tipe literasi media "advanced" akan melakukan identifikasi terhadap pengarang atau pencipta informasi dari media internet, dan selanjutnya mencari referensi yang dimuat dalam informasi tersebut.

\section{Tingkatan Literasi media Berdasarkan Social Competence}

Social competence merupakan salah satu kompetensi yang menjadi indikator dalam mengetahui tingkatan literasi media 
seseorang. Social competence terdiri dari communicative abilities, yaitu kemampuan komunikasi dan partisipasi melalui media. Communicative abilities ini mencakup kemampuan untuk membangun relasi sosial serta ber patisipasi dalam lingkungan masyarakat melalui media. Selain itu, communicative abilities ini juga mencakup kemampuan dalam membuat dan memproduksi konten media.

Terkait dengan penggunaan media internet untuk proses komunikasi sosial, saat ini siswa dihadapkan pada berbagai jenis media sosial seperti friendster, facebook, twitter, dan myspace serta bentuk media sosial lainnya. Berdasarkan temuan data, diketahui bahwa hampir seluruh siswa SMP Alam $(97,56 \%)$ memiliki akun media sosial untuk kepentingan menjalin relasi dengan saudara, teman, dan kerabat lainnya dan hanya 1 orang saja $(2,4 \%)$ yang tidak nemiliki akun di media sosial. Media sosial yang dimiliki oleh siswa sebagian besar berturutturut adalah whatsap dan line sebesar 19,5\%, yang memiliki akun medsos facebok dan whatsap sebesar $14,6 \%$ dan yang memiliki akun medsos di facebook, whatsap dan line sebesar sekaligus adalah sebesar 12,2\%. Penggunaan media sosial lain seperti twitter dan bbm cukup rendah hanya $2,4 \%$.

$$
\text { Kemampuan siswa dalam }
$$

memanfaatkan media sosial yang mereka miliki untuk menjalin relasi sosial dilihat dari jumlah pertemanan yang mereka miliki, frekuensi mereka dalam menulis status (facebook), informasi yang mereka tulis pada media sosial tersebut. Berdasarkan hasil analisis yang dilakukan terkait penggunaan media sosial tersebut didapatkan informasi bahwa kepemilikan akun media sosial tersebut digunakan mereka untuk dapat berkomunikasi dengan teman yang jauh dan untuk mendiskusikan hal-hal tertentu seperti tugas sekolah, curahan hati, dan topik-topik seputar permasalahan di sekolah.

Media sosial yang dimiliki SMP Alam Bogor sebagian $(51,2 \%)$ dimanfaatkan untuk chatting, dan sisanya 48,8 siswa pergunakan untuk menulis status di facebook. Berdasarkan temuan tersebut, diketahui bahwa aktifitas mereka dalam melakukan chatting, lebih banyak daripada aktifitas mereka mengakses media sosial lain. Chatting merupakan fasilitas yang dapat dimanfaatkan oleh seseorang untuk berkomunikasi secara tidak langsung melalui bentuk pengiriman pesan. Chatting menurut Horrigan (2002) merupakan bagian dari aktifitas kesenangan (fun activities) yang dapat dilakukan melalui media internet. Namun chatting juga dapat dimanfaatkan oleh seseorang untuk melakukan komunikasi terkait dengan hal-hal pribadi dan penting. Seperti yang dilakukan oleh siswa SMP Alam Bogor yang sebagian besar dari mereka memanfaatkan fasilitas chatting untuk mendiskusikan masalah tugas sekolah (48\%) dan masalah pribadi $(31 \%)$.

Social competence yang digunakan untuk mengetahui tingkatan literasi media seseorang menurut European Comission (2009) juga sampai mengarah pada kemampuan seseorang dalam memanfaatkan media internet untuk berpatisipasi dalam wilayah publik (public sphare). Kemampuan ini menggambarkan bagaimana seseorang bersifat kritis terhadap kondisi informasi yang berkembang di masyarakat. Pada analisis yang dilakukan ditemukan bahwa bentukbentuk partisipasi aktif siswa SMP Alam Bogor dalam wilayah publik berbentuk aktifitas memberikan komentar pada artikel yang ditulis oleh orang lain di internet, berita yang disajikan oleh berbagai jenis news media. Namun dari temuan data, terkait aktifitas ini siswa SMP Alam Bogor menunjukkan frekuensi yang rendah dalam berpartisipasi pada wilayah publik di internet, yaitu sebanyak $47 \%$ siswa menyatakan tidak pernah memberikan komentar pada blog dan tulisan orang lain pada media internet.

Kemampuan seseorang dalam memproduksi konten pada media internet yang bertujuan untuk berbagi informasi termasuk pada indikator communicative ability yang disampaikan oleh European Commision (2009) untuk mengetahui tingkatan literasi media seseorang. Ada berbagai fasilitas yang ada di internet yang memberikan peluang bagi siswa untuk memproduksi konten informasi, diantaranya 
adalah blog dan website pribadi. Blog dan website pribadi dapat dibuat oleh mereka yang memiliki kemampuan lebih dalam memproduksi konten media internet.

Kemampuan siswa dalam memanfaatkan internet untuk meningkatkan literasi media cukup baik, terlihat dari $87,8 \%$ siswa mampu memproduksi konten media berupa blog yang mereka buat sendiri, sedangkan sisanya $12,2 \%$ tidak memiliki blog sendiri. Hasil wawancara menunjukkan bahwa blog yang mereka buat mayoritas dimanfaatkan untuk memposting tugas sekolah, menulis artikel pribadi dan hal-hal terkait keseharian dan sekolah mereka, berarti kemampuan ICT mereka termasuk dalam create dan communicate informasi sudah baik walaupun masih dalam taraf sederhana.

Selain memproduksi konten media di internet berupa blog dan website, kemampuan berkreasi melalui game online juga digunakan oleh European Commision untuk mengetahui bagaimana tingkatan literasi media siswa SMP Alam Bogor. Horrigan (2002) menyatakan bahwa aktifitas bermain game adalah salah satu bentuk kreasi yang dapat dilakukan di internet untuk mencapai kesenangan tertentu (fun activities). Berdasarkan temuan 80,5\% siswa SMP Alam Bogor pernah bermain game online, dengan frekuensi (3-4 kali/minggu). Terkait dengan tingkatan literasi media siswa SMP ALam Bogor yang diukur berdasarkan kemampuan memproduksi konten dan berkreasi melalui media internet, mereka dikatakan sebagai tipe advanced. Hal ini dikarenakan frekuensi mereka dalam melakukan aktifitas tersebut cukup tinggi dan bahkan mungkin merupakan tujuan utama mereka dalam mengakses internet selain chatting.

\section{SIMPULAN DAN SARAN}

Literasi media siswa SMP Alam Bogor dalam menggunakan internet berdasarkan personal competence pada kategori technical skill tergolong pada tingkatan literasi media tipe medium. Pada kategori tersebut kemampuan siswa untuk mengakses dan mengoperasikan media cukup baik. Literasi media siswa SMP Alam Bogor dalam menggunakan internet berdasarkan personal competence pada kategori critical understanding tergolong pada tingkatan literasi media tipe advance. Pada kategori ini kemampuan siswa untuk menganalisis dan mengevaluasi konten media secara komprehensif masih dalam taraf medium. Literasi media siswa SMP Alam Bogor dalam menggunakan internet berdasarkan social competence pada kategori communicative abilities tergolong pada tingkatan literasi media tipe medium.

Berdasarkan hasil dari penelitian ini, peneliti merekomendasikan peran sekolah sebagai information and culture centre bagi siswa harus dilaksanakan secara optimal. Kemampuan literasi media sangat penting bagi siswa untuk dapat mengakses internet secara optimal dan bijak guna terpenuhinya kebutuhan informasi siswa. Aktivitas menggunakan media sosial seperti permainan game online dengan frekuensi yang tinggi perlu kontrol dari pihak sekolah.

\section{DAFTAR PUSTAKA}

American Library Association. 1989, Presidential Committee on Information Literacy: Final report. American Library Association, Chicago.

Arifianto S. 2013. Literasi media dan pemberdayaan peran kearifan lokal masyarakat. Jurnal IPTEK KOM. [http://balitbang.kominfo.go.id/balitb ang/aptikaikp/files/2013/02/LITERASIMEDIA-DAN-PEMBERDAYAANMASYARAKAT.pdf__ diunduh tanggal 16 Maret 2016]

Buckingham, D. 2005, The media literacy of children and young people: A review of the research literature on behalf of com. London, Ofcom. Available from: http://stakeholders.ofcom. Org.uk/ninaries/research/medialiteracy/ml_children.pdf [accessed 19 April 2011]. 
European Commission. 2009, Commission recommendation: on Media literacy in the Digital Environment for a More Competitive Audio Visual and Content Industry and an Inclusive Knowledge Society. Commission and the European communities, Brussels

Hartanto. 2010. Peran strategis televisi komunitas dalam pemberdayaan masyarakat. Jurnal Pengkajian dan Penciptaan Seni 6 (2): 276-294. [http://jurnal.isi-

ska.ac.id/index.php/dewaruci/article/ view/182/159 diunduh tanggal 15 Maret 2016].

Judhita C. 2013. Literasi media pada anak di daerah perbatasan Indonesia dan Timor Leste. Jurnal IPTEK Komunikasi 15 (1): 47-62. [http://balitbang.kominfo.go.id/balitb ang/bppki-

yogyakarta/files/2013/07/04_Artikel Christiany-Juditha-Juni-2013.pdf. [diunduh tanggal 12 Maret 2016].

Kriyantono R. 2007. Pemberdayaan konsumen televisi melalui ketrampilan literasi media dan penegakan regulasi penyiaran. Jurnal Penelitian Komunikasi, Media Massa, dan Teknologi Informasi. [http://rachmatkriyantono.lecture.ub. ac.id/files/2013/01/Rachmat-Jurnalttg-Media-Literacy.pdf [diunduh tanggal 13 Maret 2016].

Livingstone S. 2004. Media literacy and the challenge of new information and communication technologies. Jurnal The Communication Review. 7 (1): 3-14.

[http://www.tandfonline.com/doi/pdf /10.1080/10714420490280152\#.UoS yBnBT6j8I diunduh tanggal 14 Maret 2016].
Masitoh. 2013. Melek media khalayak pada tayangan talkshow di TV: studi kasus pada tayangan talkshow Indonesia Lawyer's Club di TV One [tesis]. Program Pascasarjana Ilmu Komunikasi Konsentrasi Ilmu Jurnalistik. Jakarta [ID]: Institut Ilmu Sosial dan Ilmu Politik.

Mudjiyanto, Bambang. 2012. Literasi Internet Dan Partisipasi Politik Masyarakat Pemilih dalam Aktivitas Pemanfaatan Media Baru. Jurnal Studi Komunikasi Dan Media. Jakarta: BPPKI. Vol. 16 No. 1. hal. 1-15.

Paulina Junni. 2007, 'Students seeking information for their Masters' theses: the effect of the Internet Header', Journal of Information Research Vol. 12 No. 2, January 2007

Pawito. 2007. Media komunitas dan lierasi media. Jurnal Ilmu Komunikasi. 4 (2): 167-177. [http://jurnal.uajy.ac.id/jik/files/2012 /05/4.-Pawito-167-178.pdf diunduh tanggal 30 Maret 2016.

Purwono. 2008. Makalah: Strategi Penelusuran Informasi Melalui Internet. Depok: Perpustakaan MBRC, FISIP UI

Sugiyono. 2008, Metode Penelitian Kunatitatif Kualitatif dan $R \& D$, Alfabeta, Bandung

Yates. 2001, Applying Diffusion Theory: Adoption of Media Literacy Programs in Schools, Applying Diffusion Theory: Adoption of Media Literacy Programs in Schools May 24-28, 2001

Sumiaty, Noneng \& Sumity, Neti. 2014. Literasi Internet pada Siswa Sekolah Menengah Pertama, Jurnal Penelitian Komunikasi, Universitas Islam Nusantara Bandung, VOL. 17 No. 1 Juli 2014, ISSN: 1410 - 8291 